\title{
Effects of Smartphone-Delivered Positive-Word Stimulation on Depressed Mood in People with Subthreshold Depression: Protocol for a Pilot Randomized Controlled Trial [Corrigendum]
}

Ejiri H, Uchida H, Tsuchiya K, Fujiwara K, Kikuchi S, The authors apologize for this error.

Hirao K. Neuropsychiatr Dis Treat. 2021;17:2739-2748.

Page 2739, Abstract, Trial Registration, the text "NCT03864484" should read "NCT04707495".

\section{Publish your work in this journal}

Neuropsychiatric Disease and Treatment is an international, peerreviewed journal of clinical therapeutics and pharmacology focusing on concise rapid reporting of clinical or pre-clinical studies on a range of neuropsychiatric and neurological disorders. This journal is indexed on PubMed Central, the 'PsycINFO' database and CAS, and is the official journal of The International Neuropsychiatric Association (INA). The manuscript management system is completely online and includes a very quick and fair peer-review system, which is all easy to use. Visit http://www.dovepress.com/testimonials.php to read real quotes from published authors. 